УДК 94(477) «2003/2018»

ПОПКО С.М.

https://orcid.org/0000-0002-3050-2517

https://doi.org/10.33577/2313-5603.31.2019.3-13

\title{
ЦИВІЛЬНИЙ ДЕМОКРАТИЧНИЙ КОНТРОЛЬ НАД ВІЙСЬКОВОЮ СФЕРОЮ В УКРАЇНІ: ЗАКОНОДАВЧЕ ЗАБЕЗПЕЧЕННЯ, ОСОБЛИВОСТІ ВПРОВАДЖЕННЯ $(2003$ - 2018)
}

Розглянуто специфіку впровадження в Україні цивільного демократичного контролю над військовою сферою, охарактеризовано основні положення Закону України «Про демократичний цивільний контроль над Воєнною організацією і правоохоронними органами держави» (2003), відзначено, що він ухвалювався 3 метою захисту національних інтересів України, утвердження і зміцнення конституційних засад демократичної, правової держави у сфері цивільно-військових відносин, забезпечення прав і свобод людини. Проаналізовано нововведення концепції демократичного контролю над Збройними Силами України (2016), Закону України «Про національну безпеку України» (2018), які вдосконалили систему цвільного демократичного контролю над воєнною сферою.

Ключові слова: Збройні Сили України, цивільний демократичний контроль, військова сфера, Міністерство оборони України.

Актуальність проблеми. У контексті російської агресії на південно-східних кордонах України, все більшої актуальності набуває проблема цивільного демократичного контролю над військовою сферою нашої держави. Експерти переконують, що запровадження цієї реформи «дозволить зменшити рівень корупції і розвантажить військове керівництво, яке повинно займатися оперативним плануванням, а не бюрократичними моментами» (Сампан).

Перші кроки у напрямі запровадження цивільного демократичного контролю над військовою сферою були здійснені ще у 90-х роках XX ст., проте необхідно зауважити, що подібні ініціативи були детерміновані насамперед зовнішньополітичними чинниками спробою інтеграції України в міжнародні структури. Це знайшло своє відображення у низці міжнародних та національних документів: «Партнерство заради миру: рамковий документ» (1994р.), «Кодекс

Попко Сергій Миколайович, Командувач Сухопутних військ Збройних Сил України, м. Київ.

(C) Попко C.M., 2019 
поведінки стосовно воєнно-політичних аспектів безпеки» (1994р.), «Концепція (основи державної політики) національної безпеки України» та інші (Поляков).

Так у підписаному Україною «Кодексі поведінки стосовно воєнно-політичних аспектів безпеки» проголошується, що «державиучасниці розглядають демократичний політичний контроль над військовими і воєнізованими силами, силами внутрішньої безпеки, а також розвідувальними службами і поліцією в якості незамінного елементу стабільності і безпеки». Відповідно до положень Кодексу Україна зобов'язалась «забезпечувати і підтримувати ефективне керівництво і контроль над своїми військовими і воєнізованими силами і силами безпеки з боку конституційно встановлених органів влади, які мають демократичну легітимність..., створювати важелі, що дозволяють забезпечити виконання такими органами покладених на них конституційних і правових обов'язків» (Поляков).

Наголосимо, що контроль над військовою сферою передбачає два взаємопов'язані принципи: демократичність та цивільність. «Якщо коротко, у класичному розумінні, дієвий цивільний демократичний контроль означає перетворення Збройних Сил у відкритий, зрозумілий для суспільства інститут, який діє в межах законодавства. Збройні сили підпорядковані демократично обраній владі та підлягають нагляду з точки зору доступу до інформації з боку ЗМІ та громадських організацій. Тому контроль має бути «демократичним» за визначенням», - зауважувала координатор проектів офісу реформ Міністерства оборони України (МОУ) О. Фаворська (Сампан).

Принцип «цивільності» забезпечується верховенством цивільних органів виконавчої, законодавчої влади і системи судочинства. «Парламент, як правило, приймає ключові рішення щодо проголошення війни та миру. Він законодавчо забезпечує, а значить контролює, оборонну політику, а також здійснює фактичний контроль за видатками на оборону в рамках бюджетного процесу», - резюмує чиновник МОУ (Сампан).

Експертне середовище України розділилось у питанні необхідності впровадження цивільного демократичного контролю над військовою сферою. Зрештою, навіть військові не до кінця усвідомлювали необхідність таких реформ, що на зламі XX - XXI ст. загальмувало законодавчий процес у цій сфері. Так, для прикладу, Л. Поляков відзначав, що «розробка і прийняття в Україні окремого закону про цивільний контроль над силовими структурами у загальному вигляді, як це намагалася зробити Державна Дума Росії, мабуть, є не 
зовсім доцільними, оскільки вдосконалення існуючої у нас системи цивільного контролю вимагає не стільки всеохоплюючих актів, скільки скрупульозного, детального поступового запровадження таких заходів, як, скажімо: вдосконалення процесу підготовки і прийняття оборонного бюджету та видатків на правоохоронну діяльність i забезпечення безпеки держави, підвищення ролі і збільшення кількості цивільних осіб у керівництві силовими структурами, створення сприятливих умов для діяльності неурядових дослідницьких центрів тощо» (Поляков).

Все ж у 2003 р. 3 метою захисту національних інтересів України, утвердження і зміцнення конституційних засад демократичної, правової держави у сфері цивільно-військових відносин, забезпечення прав і свобод людини Верховною Радою України ухвалено Закон «Про демократичний цивільний контроль над Воєнною організацією і правоохоронними органами держави» (Про демократичний изивільний контроль над Воєнною організачією і правоохоронними органами держави, 2003).

У Законі зазначено, що цивільний контроль має забезпечувати:

- пріоритет політичних підходів до вирішення питань військового будівництва, спрямування діяльності всіх складових частин Воєнної організації та правоохоронних органів на реалізацію визначених засадами внутрішньої і зовнішньої політики завдань у сфері національної безпеки і оборони, правоохоронної діяльності з метою становлення і розвитку громадянського суспільства та зміцнення конституційного правопорядку в державі, здійснення визначених Конституцією України функцій у сфері національної безпеки, оборони та зміцнення громадського порядку;

- дотримання законності в діяльності всіх складових частин Воєнної організації та правоохоронних органів держави;

- підтримання політичної стабільності в суспільстві, створення умов, які унеможливлюють використання Збройних Сил України та інших військових формувань, правоохоронних органів для обмеження прав і свобод громадян або з метою повалення конституційного ладу, усунення органів влади чи перешкоджання їх діяльності, а також в інтересах окремих осіб, політичних партій, громадських організацій;

- попередження та недопущення порушень конституційних прав і свобод, захист законних інтересів громадян України, які перебувають на службі у Збройних Силах України, інших військових 
формуваннях, утворених відповідно до законів України, та у правоохоронних органах, осіб, звільнених 3 військової служби, а також членів їхніх сімей;

- урахування громадської думки, пропозицій громадян та громадських організацій при обговоренні й ухваленні рішень 3 питань діяльності Збройних Сил України, інших військових формувань, правоохоронних органів та посадових осіб у сфері оборони, національної безпеки, зміцнення громадського порядку і законності;

- виділення відповідно до законів у необхідних обсягах і раціональне використання бюджетних коштів, спрямовуваних на утримання і функціонування Воєнної організації та правоохоронних органів держави, зокрема на реформування Збройних Сил України тощо (Про демократичний ичивільний контроль над Воєнною організачією і правоохоронними органами держави, 2003).

Предметом цивільного контролю, відповідно до Закону України «Про демократичний цивільний контроль над Воєнною організацією і правоохоронними органами держави» (ст. 5), виступають: обгрунтованість рішень державних органів з військових питань; хід виконання програм реформування Збройних Сил України, інших військових формувань; стан військово-патріотичного виховання молоді, підготовка громадян до захисту Батьківщини; питання експорту та імпорту озброєнь та військової техніки; дотримання вимог Конституції та законів України стосовно прав і свобод громадян, які перебувають на службі в Збройних Силах України, інших військових формуваннях; дотримання бюджетного законодавства; формування, фінансове забезпечення і виконання оборонного замовлення, планів мобілізаційної підготовки і мобілізації, заходів щодо утилізації та ліквідації озброєнь, попередження надзвичайних ситуацій та подолання їх наслідків; участь підрозділів Збройних Сил України в міжнародних операціях з підтримання миру і безпеки, спільних військових навчаннях; дотримання законів України при вирішенні питань про допуск підрозділів збройних сил інших держав на територію України та під час перебування їх на іiі території; дотримання законності при розгляді органами державної влади, військовими посадовими особами звернень і скарг військовослужбовців, осіб, звільнених 3 військової служби, та членів їхніх сімей (Про демократичний цุивільний контроль над Воєнною організачією $і$ правоохоронними органами держави, 2003).

Суб'єктами цивільного контролю над воєнною організацією держави визначені: а) Верховна Рада України; б) Уповноважений 
Верховної Ради України з прав людини; в) Президент України; г) Рада національної безпеки і оборони України; д) Кабінет Міністрів України; е) центральні та місцеві органи виконавчої влади в межах повноважень, визначених законом; є) органи місцевого самоврядування в межах повноважень, визначених законом; ж) прокуратура України; з) судові органи України; и) громадяни України та громадські організації; і) засоби масової інформації (Про демократичний ичвільний контроль над Воєнною організацією і право охоронними органами держави, 2003).

Значні повноваження у сфері демократичного цивільного контролю надано Президенту України, який:

- вносить на затвердження Верховної Ради України пропозиції щодо загальної структури, чисельності, визначення функцій Збройних Сил України, Служби безпеки України, інших утворених відповідно до законів України військових формувань, а також Міністерства внутрішніх справ України;

- призначає на посади та звільняє з посад вище командування Збройних Сил України, інших військових формувань, правоохоронних органів; присвоює вищі військові звання;

- вносить до Верховної Ради України пропозиції про оголошення стану війни та приймає рішення про використання Збройних Сил України в разі збройної агресії проти України;

- приймає відповідно до закону рішення про загальну або часткову мобілізацію та введення воєнного стану в Україні або в окремих iї місцевостях у разі загрози нападу, небезпеки державній незалежності України з внесенням рішення на затвердження Верховною Радою України;

- приймає у разі необхідності рішення про введення в Україні або в окремих іiі місцевостях надзвичайного стану, а також оголошує в разі необхідності окремі місцевості України зонами надзвичайної екологічної ситуації з визначенням участі в здійсненні пов'язаних із цим заходів Збройних Сил України та інших військових формувань - 3 наступним затвердженням цих рішень Верховною Радою України (Про демократичний цивільний контроль над Воєнною організацією і правоохоронними органами держави, 2003).

На жаль, констатуємо, що парламентський контроль над військовою сферою в Україні залишається слабким і малоефективним. «Парламент може впливати лише на призначення Міністра оборони і Міністра внутрішніх справ та Голови СБУ, хоча, після їх призначення, системного контролю за ними вже немає. А на призначення 
ïx заступників, а також керівників служб та інших військових формувань український парламент впливу не має взагалі», - констатують експерти (Цивільний контроль над військовими в Україні: до питання ефективності й системності).

Центральні органи виконавчої влади організовують і забезпечують виконання законів України, інших нормативно-правових актів стосовно національної безпеки і оборони та правоохоронної діяльності, а також створюють необхідні умови для здійснення іншими суб'єктами демократичного цивільного контролю передбачених законами повноважень (Про демократичний цивільний контроль над Воєнною організацією і правоохоронними органами держави, 2003). Органи місцевого самоврядування, місцеві державні адміністрації контролюють хід допризовної підготовки, відбір військовими комісіями громадян призовного віку на військову службу; забезпечують виконання законодавства стосовно дотримання прав та соціальних гарантій громадян, які можуть бути призвані на військову службу, перебувають на військовій службі, звільнені з військової служби, та членів їхніх сімей; сприяють розташованим на відповідній території підрозділам Збройних Сил України та інших військових формувань, правоохоронним органам у виконанні покладених на них завдань тощо (Про демократичний ичвільний контроль над Воєнною організацією і правоохоронними органами держави, 2003).

Окрему увагу необхідно звернути на участь громадян у здійсненні контролю (через громадські організації, членами яких вони $\epsilon$, через депутатів представницьких органів влади, так і особисто, шляхом звернення до Уповноваженого Верховної Ради України 3 прав людини та його представника у справах захисту прав військовослужбовців), а також 3МІ.

Мас-медіа, зокрема, отримали право:

- запитувати та безоплатно отримувати від органів військового управління, інших органів державної влади, організацій, підприємств і установ, які належать до Воєнної організації держави, правоохоронних органів, відкриту інформацію, документи і матеріали 3 питань, віднесених до їхньої компетенції. Керівники відповідних органів, установ, підприємств і організацій зобов'язані безперешкодно надавати таку інформацію;

- поширювати отриману інформацію через пресу, радіо, телебачення, засоби глобальної інформаційної мережі Інтернет та в інший спосіб, дотримуючись вимог законодавства щодо збереження державної таємниці; 
- публікувати офіційні відповіді органів державної влади та військового управління на матеріали, що були оприлюднені раніше тощо (Про демократичний ичиільний контроль над Воєнною організачією і правоохоронними органами держави, 2003).

Теоретичні напрацювання у сфері законодавчого забезпечення демократичного цивільного контролю над військовою сферою не дали очікуваних результатів. Каталізатором нової хвилі реформ послужила російська агресія (2014р.). У відповідь на збройну агресію з боку Російської Федерації Україна розпочала здійснювати комплексні заходи з метою розбудови ефективної системи оборони, які мали на меті два головних паралельних завдання: стримати Росію від повномасштабного вторгнення та відновити контроль над регіонами, контрольованими сепаратистами (Цивільний контроль над військовими в Україні: до питання ефективності й системності). «Важливо пам'ятати, що в демократичній державі, якою є Україна, ефективність вирішення зазначених питань напряму залежала і залежить від ефективності системи демократичного цивільного контролю над військовими, - констатують учені. - У цьому контексті $\epsilon$ ряд питань, які довелося терміново вирішувати, зокрема, опрацьовувати нові концептуальні документи у сфері національної безпеки та вдосконалювати законодавство...» (Цивільний контроль над військовими в Украӥні: до питання ефективності й системності).

У 2015 р. були ухвалені необхідні концептуальні документи стратегічного рівня - Стратегія національної безпеки України та Воєнна доктрина України, прийняті нові та удосконалені існуючі законодавчі акти у сферах регуляції загальнодержавних процесів координації та управління у секторі безпеки, здійснення адміністративного контролю на територіях, суміжних із зоною конфлікту, та покращення управлінських механізмів під час особливого періоду за рахунок уточнення важливих деталей правового режиму воєнного стану. У 2016 р. прийнято ще декілька важливих концептуальних документів, зокрема Стратегічний оборонний бюлетень (СОБ) (Цивільний контроль над військовими в Україні: до питання ефективності й системності).

31 жовтня 2016 р. Проектний офіс реформ МОУ на міжнародному семінарі в Національному університеті оборони України імені I. Черняховського презентував нову Концепцію демократичного контролю над Збройними Силами України. Заступник Міністра оборони І. Долгов пояснив необхідність цивільного контролю над 
3СУ: «Перше: всі громадяни платять податки і на ці податки утримуються Збройні сили. Друга відповідь - це те, що на цю силу покладено певні функції - територіальної цілісності, незалежності, суверенітету держави. Таким чином, контроль повинен забезпечити, щоб Збройні сили були в змозі виконати цю функцію. І третє: цивільний контроль потрібен для того, щоб забезпечити повну деполітизацію Збройних сил від внутрішньополітичних процесів» (Цивільний міністр оборони і деполітизація армії: в Києві представили Концุепиію циивільного контролю над ЗСУ). Також наголошено, що впровадження цивільного контролю над ЗСУ відбудеться в рамках Стратегічного військового бюлетеня, де знаходимо пункт про те, що цивільні люди повинні отримати можливість працювати в Міноборони та інших силових структурах і отримувати заробітну плату на рівні з військовими. Концепція розроблена за посередництва ОБСЄ з урахуванням досвіду цивільного контролю над армією в інших країнах, зокрема Австрії та Болгарії (Цивільний міністр оборони і деполітизація армії: в Києві представили Конщепцію циивільного контролю над ЗСУ).

Учені констатують, що протягом трьох років (2014 - 2016 рр.) «Україні вдалося відреагувати та вирішити немало проблем функціонування системи демократичного цивільного контролю. Однак, для повноцінного забезпечення національних інтересів України потрібно докласти ще багато зусиль, особливо, для запровадження дієвих практичних інструментів контролю й подальшого наближення ситуації у цій сфері загалом до загальноприйнятих демократичних норм» (Цивільний контроль над військовими в Україні: до питання ефективності й системності).

Після ухвалення Закону України «Про національну безпеку України» від 21 червня 2018 р. Закон України «Про демократичний цивільний контроль над Воєнною організацією і правоохоронними органами держави» втратив чинність. У Законі третій розділ присвячений демократичному цивільному контролю. Зокрема законодавець передбачив, що система цивільного контролю складається 3 контролю, що здійснюється Президентом України; контролю, що здійснюється Верховною Радою України; контролю, що здійснюється Радою національної безпеки і оборони України; контролю, що здійснюється Кабінетом Міністрів України, органами виконавчої влади та органами місцевого самоврядування; судового контролю; громадського контролю (Про національну безпеку України, 2018). 
Відповідно, предметом цивільного контролю є: а) дотримання вимог Конституції і законів України у діяльності органів сектору безпеки i оборони, недопущення їх використання для узурпації влади, порушення прав і свобод людини та громадянина; б) зміст і стан реалізації стратегій, доктрин, концепцій, державних програм та планів у сферах національної безпеки і оборони; в) стан правопорядку в органах сектору безпеки і оборони, їх укомплектованість, оснащеність сучасним озброєнням, військовою і спеціальною технікою, забезпеченість необхідними запасами матеріальних засобів та готовність до виконання завдань за призначенням у мирний час та в особливий період; г) ефективність використання ресурсів, зокрема бюджетних коштів, органами сектору безпеки і оборони (Про національну безпеку України, 2018).

Таким чином, запровадження демократичного цивільного контролю над воєнною сферою - нагальна необхідність в умовах російської агресії та євроатлантичної інтеграції України. Підвищення ефективності діяльності МОУ, посилення зв'язків Збройних Сил України з Верховною Радою України і громадянським суспільством пріоритети у цій сфері (Сампан). 2019 - 2020 рр. повинні показати ефективність законодавства України та готовність військових до нововведень.

\section{Використані посилання}

Поляков Л. Цивільний контроль над силовими структурами [online] Доступно: <http://old.razumkov. org.ua/ukr/article. php? news_id=18> [Дата звернення: 22 грудня 2018].

Про демократичний цивільний контроль над Воєнною організацчією і правоохоронними органами держави. Закон України. [online] Доступно: <http://zakon3.rada.gov.ua/laws/show/975-15> [Дата звернення: 23 грудня 2018].

Про національну безпеку України. Закон України [online] Доступно: <http://zakon.rada.gov.ua/laws/show/2469-19> [Дата звернення: 22 грудня 2018].

Сампан I. Демократичний контроль над ЗСУ. Що це таке $i$ для чого Украӥні цивільний міністр оборони? [online] Доступно: $<$ https://ua.112.ua/interview/demokratychnyi-kontrol-nad-zsu-shchotse-take-i-dlia-choho-ukraini-tsyvilnyi-ministr-oborony-428250.html> [Дата звернення: 27 грудня 2018]. 
Цивільний контроль над військовими в Україні: до питання ефективності й системності [online] Доступно:

$<$ http://timeua. info/post/oborona-i-bezopasnost/civ-1-nij-kontrolnad-v-js-kovimi-v-ukra-n--do-pitannya-efektivnost--j-sistemnost-07862.html> [Дата звернення: 22 грудня 2018].

Цивільний міністр оборони і деполітизачія армії: в Києві представили Концепщію цивільного контролю над ЗСУ [online] Доступно: <https://ua.censor.net.ua/n412969> [Дата звернення: 24 грудня 2018].

\section{References}

Polyakov L. Civil control over power structures. [online] Available at: 〈http://old.razumkov.org.ua/ukr/article.php?news_id=18> [Accessed 22 December 2018] (ukr).

On democratic civilian control of the military organization and law enforcement bodies of the state. Law of Ukraine. [online] Available at: 〈http://zakon3.rada.gov.ua/laws/show/975-15> [Accessed 23 December 2018] (ukr).

On national security of Ukraine. Law of Ukraine. [online] Available at: 〈http://zakon.rada.gov.ua/laws/show/2469-19> [Accessed 22 December 2018] (ukr).

Sampan I. Democratic control over the armed forces. What is it and why Ukraine is a civilian defense minister? [online] Available at: $<$ https://ua.112.ua/interview/demokratychnyi-kontrol-nad-zsu-shchotse-take-i-dlia-choho-ukraini-tsyvilnyi-ministr-oborony-428250.html> [Accessed 27 December 2018] (ukr).

Civilian control over the military in Ukraine: to the question of efficiency and systemicity. [online] Available at:

$<$ http://timeua.info/post/oborona-i-bezopasnost/civ-l-nij-kontrolnad-v-js-kovimi-v-ukra-n--do-pitannya-efektivnost--j-sistemnost-07862.html> [Accessed 22 December 2018] (ukr).

Civilian minister of defense and depoliticization of the army: in Kiev presented the concept of civilian control over the armed forces. [online] Available at: <https://ua.censor.net.ua/n412969> [Accessed 24 December 2018] (ukr). 


\section{Popko S.}

\section{CIVILIAN DEMOCRATIC CONTROL OVER THE MILITARY SPHERE IN UKRAINE: LEGISLATIVE SUPPORT, PECULIARITIES OF IMPLEMENTATION (2003-2018)}

The main provisions of the Law of Ukraine «On Democratic Civilian Control over the Military Organization and Law Enforcement Bodies of the State» (2003) were characterized; it was emphasized that the law was approved to protect the national interests of Ukraine, to establish and strengthen the constitutional principles of a democratic state, a country with the rule of law in the field of civil-military relations, ensuring human rights and freedoms.

It was noted that according to legislative acts, the civilian control should ensure the priority of political approaches to the solution of military construction issues, direct the activities of all components of the Military Organization and law enforcement agencies to implement the tasks defined in the framework of national and foreign policy in the field of national security and defense, law enforcement activities in order to establish and develop civil society, to exercise the functions defined in the Constitution of Ukraine in the sphere of national security, defense and strengthening of public order.

The new developments of the Concept of the Democratic Control over the Armed Forces of Ukraine (2016), the Law of Ukraine «On National Security of Ukraine» (2018), which improved the system of the civilian democratic control over the military sphere, were analyzed. It was noted that according to the above-mentioned documents, the system of civilian control consists of the control carried out by the President of Ukraine; the Verkhovna Rada of Ukraine, the National Security and Defense Council of Ukraine, the Cabinet of Ministers of Ukraine, executive bodies and local self-government bodies, as well as judicial and public control.

Keywords: Armed forces of Ukraine, civilian democratic control, military sphere, ministry of defense of Ukraine. 